\title{
Prevalence and Correlates of Depressive Disorders among People Living with HIV/AIDS, in North Central Nigeria
}

\author{
Shittu RO ${ }^{1 *}$, Issa BA², Olanrewaju $\mathrm{GT}^{2}$, Mahmoud AO ${ }^{3}$, Odeigah LO', Salami AK ${ }^{4}$ and Aderibigbe SA \\ ${ }^{1}$ Department of Family Medicine, Kwara State Specialist Hospital, Sobi, Ilorin, Nigeria \\ ${ }^{2}$ Department of Behavioural Sciences, University of Ilorin Teaching Hospital, Ilorin, Nigeria \\ ${ }^{3}$ Department of Ophthalmology, University of Ilorin Teaching Hospital, Nigeria \\ ${ }^{4}$ Department of Internal Medicine, University of Ilorin Teaching Hospital, Nigeria \\ ${ }^{5}$ Department of Epidemiology and Community Health, University of Ilorin Teaching Hospital, Nigeria
}

\begin{abstract}
Background: Depressive disorders are a significant public health issue. They are prevalent, disabling, and often chronic, with a high economic burden to the society. Although depression is common, determining its prevalence across studies and within different segments of the HIV population is not easy, given the variety of methodological issues that warrant consideration. This study estimates the prevalence of depressive disorders and its correlates.
\end{abstract}

Objectives: The study sought to determine the prevalence of depression among adults, HIVIAIDS respondents, attending HIVIAIDS clinic in Kwara State specialist Hospital, Sobi, Ilorin, Nigeria.

Methods: This was a hospital based, cross sectional, descriptive study of three hundred adult HIVIAIDS patients attending the HIV clinic of Kwara State specialist hospital, Sobi, llorin from $1^{\text {st }}$ of March to $30^{\text {th }}$ July, 2013. Informed consent was obtained from the respondents. The PHQ-9 was administered to the respondents to screen for depression. A pre-tested PHQ-9 questionnaire was used to collect data. Subject who scored one and more were assessed clinically for depression. The severity of the depression was further classified as minimal, mild, moderate and severe. The three keys of social determinants of depression (SDS) were assessed and the association with depression sought.

Results: One hundred and seventy $(56.7 \%)$ satisfied the criteria for a depressive disorder using the PHQ-9 score. Depressive symptoms were strongly related to gender, below average year of schooling, poor economic status, low social cohesion, and stressful life events.

Conclusion: Clinicians should assess HIV-infected subjects for depression, to ensure early detection and treatment. Failure to recognize depression may endanger both the subjects and others in the community. This result calls for improved public health education and awareness programme, to highlight the health impact of depressive symptoms among People Living with HIVIAIDS (PLWHA).

Keywords: Prevalence; Depression; HIV/AIDS; Correlates

\section{Introduction}

The World Health Organization predicted that by the year 2020, depression will be the leading cause of worldwide disability [1]. In its September 9, 2005, Morbidity and Mortality Weekly Report, the Centers for Disease Control and Prevention (CDC) acknowledged that presence of depression in subjects with chronic illness adversely affect the management and outcome of chronic illnesses. The CDC called for public agencies to "incorporate" mental health promotion into chronic disease prevention efforts [2]. Ohaeri and colleague at Ibadan, reported that at least $49 \%$ of the patients attending the general outpatients clinic at University College Hospital in Ibadan had a significant number of depressive symptoms, occurring either as the only the symptom or as part of their physical illness [3].

Depression silently destroys families and ruins careers of affected individuals. It is debilitating, progressive, relentless and age's patient's prematurely [4]. It is the key predictors of poor adherence to HIV medication, [5,6] and has negatively impact on clinical outcomes [7]. The negative impact of depression on the course of HIV may manifest in maladaptive self care behaviours. Indeed, depression has been shown to be associated with sexual risk taking, [8] substances abuse [9] and poor adherence to HAART [10]. Poor adherence to antiretroviral treatment regimes has serious consequences for HIV-infected patients, including failure to prevent viral replication and an increased risk of developing viral resistance. Moreover, it keeps people out of the workplace, reduces productivity at school and work, and has tremendous negative effects on the economy. People who suffer from depression are nearly 28 times more likely to miss work because of emotional disability [4].

There are nine symptoms listed in the Diagnostic and Statistical Manual IV (DSMIV) [11] for depressive disorder namely, sleep disturbance, interest/pleasure reduction, guilt feelings or thoughts of worthlessness, energy changes/fatigue, concentration/attention impairment, appetite/weight changes, psychomotor disturbances, suicidal thoughts and depressed mood. For diagnosis of major depression, five of the nine must be present for at least two weeks and one of those five must be loss of interest or pleasure or depressed $\operatorname{mood}[4]$

*Corresponding author: Shittu RO, Consultant Family Physician, Department of Family Medicine, Kwara State Specialist Hospital, Sobi, Ilorin and The Chief Medical Director, Oorelope Hospital, KM 8, Apata Yakuba, Ilorin, Kwara State Nigeria, Tel: +2348035062687; E-mail: oorelopehospital@gmail.com

Received September 03, 2013; Accepted September 30, 2013; Published October 12, 2013

Citation: Shittu RO, Issa BA, Olanrewaju GT, Mahmoud AO, Odeigah LO, et al. (2013) Prevalence and Correlates of Depressive Disorders among People Living with HIVIAIDS, in North Central Nigeria. J AIDS Clin Res 4: 251. doi: 10.4172/21556113.100025

Copyright: @ 2013 Shittu RO, et al. This is an open-access article distributed unde the terms of the Creative Commons Attribution License, which permits unrestricted use, distribution, and reproduction in any medium, provided the original author and source are credited. 
There is good evidence that screening improves the accurate identification of patients with depression in primary care settings. The U.S Preventive Task Force (USPSTF) found good evidence that programs combining depression screening and feedback with staffassisted depression care supports improve clinical outcomes in adults and older adults [12]. The USPSTF found fair evidence that screening and feedback alone without staff-assisted care supports does not improve clinical outcomes in adults and older adults [12]. The USPSTF found no evidence of harms of screening for depression in adults or older adults [12].

The scientific literature on the prevalence of depression in PLWHA is contradictory. Ciesla and co-workers [12] estimated that major depression is twice as frequent in HIV-positive patients when compared with HIV-negative patients while Kaplan and co-workers [13] reported that up to $40 \%$ of HIV-positive patients met the diagnostic criteria for depressive disorders. Morrison et al. [14] gives the rate of depression to be 4 times higher in HIV sero-positive women when compared with HIV sero-negative women. The National Institute of Mental Health [15] however, believes that s many as 1 in 3 persons with HIV may suffer for depression.

Variation in social-cultural and economic factors may account for the differences in reported depression prevalence in the various studies across the globe. Economic status or variables related to income or financial status is reported to be significant determinant of depression $[16,17]$. The socio demographic factors of age, gender, marital status, education and income are important factors, in explaining the variability in depression prevalence rates [18-21]. Pattern [19] found significant interaction among age, sex, marital status and depression. Prevalence of depression has also been found to vary considerably based on gender [22]. Consistently, women have nearly double or triple prevalence rates than men. Traditionally, there is an association between depression and Socio-Economic Status (SES).

Several recent studies confirmed a strong inverse relationship between SES and mental disorder [23]. People in the lowest socioeconomic class are more likely to suffer from psychiatric disorder, than those in the highest class [24].

Social Support and Social Cohesion have been identified as playing major roles in depression [25]. While Social support enables people to negotiate life's crisis, social cohesion helps to stabilize health threatening situations by including and accepting people, and by enabling them to participate freely within the families, the committees and the society [26]. There is evidence that lack of social supports, increase the risk of depression [27].

Depression is under-recognized and under-treated in HIV-infected individuals. Given the availability of simple self-reported screening instrument for in primary care, neglect of this aspect of care for peoples with HIV infection is reprehensible. The aim of this study was to determine the prevalence and determinants of depressive disorders among HIV/AIDS subjects attending HAART Clinic in Kwara State Specialist Hospital, Sobi, Ilorin, Nigeria.

\section{Methodology}

This study was conducted at a designated HIV/AIDS treatment centre in the Sobi Specialist Hospital, Ilorin, Kwara State, located in the North Central Nigeria. It was established by the Kwara State Government in April, 1985. The HIV/AIDS treatment centre took off in the hospital in May, 2009. Eight hundred patients have been enrolled and over six hundred are on Highly Active Antiretroviral
Therapy (HAART). The centre is currently being founded by a NonGovernmental Organization (NGO), Friends for Global Health.

This was a descriptive, cross-sectional study carried out from $1^{\text {st }}$ of March to $30^{\text {th }}$ July, 2013. The inclusion criteria were all consented HIV/AIDS positive respondents, who presented at the Clinic. The exclusion criteria were the critically ill subjects and those who refused to participate. The PHQ-9 was administered to all the respondents, to screen for depression, until the estimated sample size of 300 was obtained. Respondents who scored one and more were assessed clinically for depression. The severity of the depression was further classified as minimal, mild, moderate and severe. The three keys of social determinants of depression (SDS) were assessed and the association with depression sought.

The sample size was estimated using the Fisher formular [28], using $21.3 \%$ from a previous study [29], as the best estimate of depressive disorders among People Living with HIV/AIDS. A minimum size of 218 was calculated using Fisher's formula but 300 was used to increase the power and reliability of the study. Pretesting was carried out at the Kwara State Civil Service Hospital, using 30 respondents (10\% of the sample size).

Ethical approval was obtained from the Ethical Review Committee of the Kwara State Ministry of Health before commencement of the study. The respondents were adequately informed about the nature of the study and its benefits. An informed consent was obtained from each participant, after adequate information about the study. An interviewer administered questionnaire was used. However, for subjects who do not understand English, a local dialect version of the instrument was used. These were arrived at, through the process of translation and back translation by panel of bilingual experts.

Based on existing research [30-32], we used three key SDH: socioeconomic status, social cohesion and negative life events (Appendix A). Socioeconomic status included two indicators: years of schooling and self-reported economic status of the family, in general, in the previous year. Categories for years of schooling were as follows: above average ( 7 years and above), average (1-6 years) and below average (0 year). Economic status of the family was self-reported as good, average or poor. Social cohesion was assessed from responses to two questions: (1) in the previous year, how often did you ask someone for help when you had problems? $($ Never $=1$; Seldom $=2$; Sometimes $=3$; Often $=4$ ), and when you had problems? (spouse or lover; parents, brothers, sisters or children; other relatives; people outside the family; organization or schools with whom you are affiliated; government, party or trade unions; religious or non-governmental organizations; other organizations) $(\mathrm{No}=0 ;$ Yes $=1)$. Negative life events were assessed using a 12-item scale (serious illness in oneself, serious illness in the family, financial difficulties, conflict with spouse, conflict with other family members, conflict with people in the village, conflict between family members, infertility issues, problems at work or school, problems in an intimate relationship, abuse and other events) [33]. For each life event that occurred in the last year, or that occurred earlier but continued to have a psychological effect during the past 12 months, the respondents indicated when the life event occurred, its effect (positive or negative) and the length of time over the last year that the psychological effect lasted. We used the sum of the number of life events with a negative effect as a measure of negative life events.

Age, gender, marital status, education level, self-rated financial status, social support and social cohesion, employment status and estimated monthly income were the socio-demographic variables and 
potential confounders. Marital status was grouped as either married or unmarried, which included the never married, divorced, separated and widowed/widower. Educational level had 4 ordinal groups (no formal education, primary education, secondary education and tertiary education). Occupation was grouped into traders, civil servants, self employed, unemployed and students. Monthly income was assessed using the minimum wage stipulated by the Federal Government of Nigeria, which was put approximately at Twenty Thousand Naira $(\mathrm{N} 20,000)$ equivalent to $(\$ 125)$ us dollars. Four clinical interview questions, the CAGE questions was used to make a diagnosis of alcohol misuse. The questions focused on Cutting down in Appendix B, Annoyance by criticism, Guilty feeling, and Eye-openers [34].

The Patients Health Questionnaire (PHQ-9) [35] is a brief, 9-item, patients self-report depression assessment tool that was derived from the interview-based PRIME-MD [33] (Appendix C). It was specifically developed for use, in primary care general medical settings. Many depression screening and severity tools have been used in primary care, with good results. The PHQ-9, however, offers several advantages to other tools. Because the items and the scoring of items on the PHQ-9 are identical to the symptoms and signs of DSM-4 major depression, the tool is easily understood with very high face validity for patients and clinicians in primary care. Many other instruments use a 1-week time frame, but the PHQ-9 uses a 2-week time frame, which conforms to DSM-4 criteria. It is the only tool that was specifically developed for use as a patient self-administered depression diagnostic tool, rather than as a severity or screening tool. It is the only short self-report tool that can reasonably be used both for diagnosis of DSM-4 major depression as well as for tracking of severity of major depression over time [36]. Psychometric evaluation of the PHQ-9 revealed a sensitivity ranging from $62 \%-92 \%$ and a specificity between $74 \%-88 \%[33,35,36]$. All subjects screened positively for depression using Patients Health Questionnaire - 2 (PHQ-2), which was the first two questions of PHQ9, triggered full diagnostic interviews by the behavioural scientists. Scoring and level of depression was accessed viz: (1-4) Minimal depression, (5-9) Mild depression, (10-14) Moderate depression, (1519) moderately severe depression, and (20-27) severe depression. Some direct depression care, such as care support, coordination, case management, and treatment was embarked on.

Completed questionnaire and measurements were entered into a computer data base. The data were analyzed using the epidemiological information (Epi-info) 2005 software package of Center for Disease Control and Prevention (CDC). The 2 by 2 contingency tables were used to carry out Chi-square test and to find out the level of significance and values less than 0.05 were regarded as statistically significant.

\section{Results}

Table 1, shows the socio-demographic characteristics of the respondents. A total of one hundred and seventy sero-positive respondents with depression were recruited to the study. The age range 36-40 years had the highest number of respondents 50(29.4\%). Females $139(81.8 \%)$ outnumbered males $31(18.2 \%)$ giving a male: female ratio of 1:4.5. Predominantly, $139(81.8 \%)$ were Muslims, why Christian constituted $30(17.6 \%)$. Fourteen $(8.2 \%)$ were married while the same number were single. One hundred and sixteen (68.3\%) were separated/ divorce while 26(15.3), were widow/widower. The majority of them $56(32.9 \%)$ had no formal education, 55(32.4\%), had primary education while $42(24.7 \%)$ had secondary education. Only $17(10.0 \%)$ attended tertiary institution. Majority, 91(53.5\%) were traders, while $14(8.2 \%)$ were unemployed. Six (3.5\%) were students.

\begin{tabular}{|c|c|c|c|}
\hline Variable & $N=170$ & (\%) & \\
\hline $\begin{array}{l}\text { Age group (years) } \\
<26 \\
26-30 \\
31-35 \\
36-40 \\
41-45 \\
46-50 \\
51-55 \\
56-60 \\
>60\end{array}$ & $\begin{array}{c}19 \\
27 \\
20 \\
50 \\
11 \\
19 \\
6 \\
11 \\
7\end{array}$ & $\begin{array}{c}11.2 \\
15.9 \\
11.8 \\
29.4 \\
6.5 \\
11.1 \\
3.5 \\
6.5 \\
4.1\end{array}$ & $\begin{array}{l}\text { Mean age is } 39 y \text { with } \\
\text { SD of } \pm 10.8\end{array}$ \\
\hline $\begin{array}{l}\text { Gender } \\
\text { Male } \\
\text { Female }\end{array}$ & $\begin{array}{c}31 \\
139\end{array}$ & $\begin{array}{l}18.2 \\
81.8\end{array}$ & \\
\hline $\begin{array}{l}\text { Ethnicity } \\
\text { Hausa } \\
\text { Yoruba } \\
\text { lgbo } \\
\text { Others }\end{array}$ & $\begin{array}{l}39 \\
92 \\
28 \\
11\end{array}$ & $\begin{array}{c}22.9 \\
54.1 \\
16.5 \\
6.5\end{array}$ & \\
\hline $\begin{array}{l}\text { Religion } \\
\text { Christianity } \\
\text { Islam } \\
\text { Traditional }\end{array}$ & $\begin{array}{c}30 \\
139 \\
1\end{array}$ & $\begin{array}{c}17.6 \\
81.8 \\
0.6\end{array}$ & \\
\hline $\begin{array}{l}\text { Marital Status } \\
\text { Single } \\
\text { Married } \\
\text { Separated/Divorced } \\
\text { Widowed/Widower }\end{array}$ & $\begin{array}{c}14 \\
14 \\
116 \\
26\end{array}$ & $\begin{array}{c}8.2 \\
8.2 \\
68.3 \\
15.3\end{array}$ & \\
\hline $\begin{array}{l}\text { Educational level } \\
\text { Non-Formal } \\
\text { Primary } \\
\text { Secondary } \\
\text { Tertiary }\end{array}$ & $\begin{array}{l}56 \\
55 \\
42 \\
17\end{array}$ & $\begin{array}{l}32.9 \\
32.4 \\
24.7 \\
10.0\end{array}$ & \\
\hline $\begin{array}{l}\text { Occupation } \\
\text { Trader } \\
\text { Civil servant } \\
\text { Self employed } \\
\text { Unemployed } \\
\text { Students }\end{array}$ & $\begin{array}{l}91 \\
16 \\
43 \\
14 \\
6\end{array}$ & $\begin{array}{c}53.5 \\
9.4 \\
25.4 \\
8.2 \\
3.5\end{array}$ & \\
\hline $\begin{array}{l}\text { Monthly Income (N) } \\
\text { No Income } \\
\leq 20000(\$ 125) \\
20001-30000(\$ 187) \\
30001-40000(\$ 250) \\
40001-50000(\$ 312) \\
>50000(\$ 312)\end{array}$ & $\begin{array}{c}20 \\
129 \\
10 \\
6 \\
3 \\
2\end{array}$ & $\begin{array}{c}11.8 \\
75.9 \\
5.8 \\
3.5 \\
1.8 \\
1.2\end{array}$ & \\
\hline
\end{tabular}

Table 1: Socio-Demographic Characteristics of Respondents.

LEVELS OF DEPRESSION USING THE PATIENTS HEALTH QUESTIONNAIRES (PHQ-9) SCALE



Figure 1: Levels of Depression among the Respondents, Using the Patients Health Questionnaires (PHQ-9) Scale.

Figure 1 shows that $170(56.7 \%)$ satisfied the criteria for a depressive disorder using the PH-9 score. Among the cases, 109(36.3\%) had minimal depression, while $4(13 \%)$ were severely depressed. 
Figure 2, displays the CAGE questionnaire. Fifty two (30.6\%) respondents had at one time or the other engaged in alcohol intake. Twenty seven (52\%), respondents scored 4, 13(25\%), scored 3, 7(13.5\%), scored 7, 4(7.6\%) scored 1, while 1(1.9\%) scored 0 in all. Therefore $47(90 \%)$ respondents had a total score of 2 or greater which is of clinical significant (sensitivity of $93 \%$ and a specificity of $76 \%$ for the identification of problem drinking).

Table 2, displays the variation according to self reported economic status of the family, years of schooling, social cohesion in the previous year and negative life events. Eighty-eight (51.8\%) had poor, $62(36.5 \%)$, had average, while $20(11.8 \%)$ had good self reported economic status. Those with below average year of schooling, 80(47.1\%) respondents were more depressed than those with above average year of schooling, $45(26.5 \%)$. This is statistically significant ( $\mathrm{p}$-value $=0.03$ ). Negative life events were associated with depression. Twenty-two (70.9\%) males and $62(44.6 \%)$ females had one or two negative live events whereas 9(29.1\%) males and 45(32.3\%) female's respondents had more than three negative life events.

\section{Discussion}

The prevalence of depressive disorders among HIV/AIDS patients attending the Highly Active Anti-Retroviral Therapy (HAART) clinic,

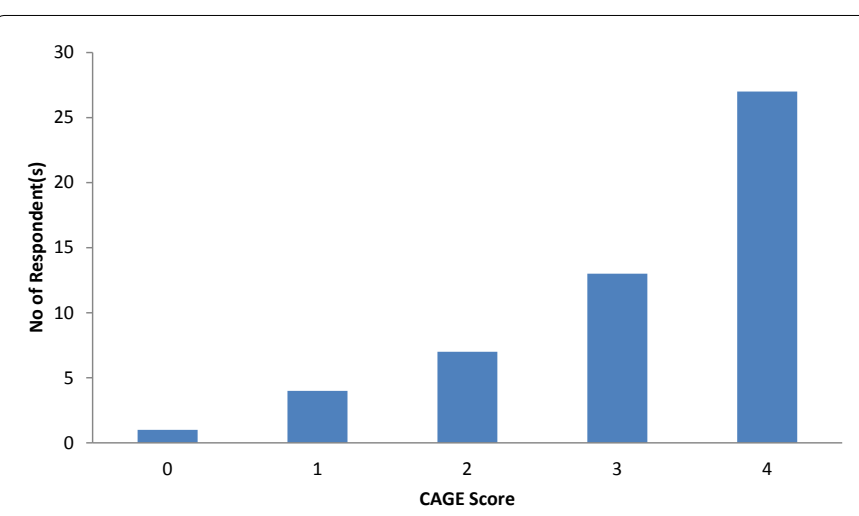

Figure 2: Evaluating the Cage Questionnaire for Alcohol Misuse among the Respondents. at the Kwara State Specialist Hospital Sobi, was 57\%. Depressive symptomatology in the population, mirrored presentation of depression in other setting [35]. The study replicates previous findings concerning the prevalence of depressive disorders among People Living with HIV/ AIDS (PLWHs) patients in Nigeria in particular. It also falls within the rates seen internationally $[37,38]$.

Pence et al. [38], in the United State reported 36\% while Bing [36] and co-workers in their study, psychiatric disorder and drug use among HIV infected adults in the United State reported 35\% [35,37]. Asch et al. [35] while determining the socio demographic and service delivery correlates of depression in the United States of America under diagnosis in HIV used Composite International Diagnosis Interview (CIDI) and 37\% had CIDI-defined major depression [38]. Sullivan, at the University of Sydney, Australia while studying the psychosocial determinant of depression found a 3-monght prevalence of depressive symptoms among Farranfore and Penrith respondents to be $30 \%$ and $35 \%$ respectively [39]. Judd and colleagues at the centre for rural mental health, school of psychiatry, psychology and psychological medicine, Monash University, Australia found a prevalence of $27 \%$ using the structured clinical interview rating [40]. Musisi and co-workers while comparing the clinical features of depression in HIV positive and HIV negative patients in Uganda found a prevalence of $15.6 \%$ [41]. Israeethika and colleagues, while studying the effect of cognitive behaviour therapy and changes of depressive symptoms among Thai Adult HIV-infected patients found a prevalence of 30\% [42]. Bongogo and co-workers [41] reported that among 117 participants, 81 (69.2\%) had mild depressive features $2(1.7 \%)$ had moderate depressive features, $1(0.9 \%)$ had severe depressive features and $33(28.2 \%)$ did into have depressive features. Depressive features were more common in male (77.1\%) than the females (69.5\%) [43]. Valeria and co-workers while studying 120 Brazilian women living with HIV used the Structured Clinical Interview for DSM-IV Axis 1 Disorders and the prevalence was 25.8\% [44]. In Malaysia, Tung Yee while studying depression among the Human Immunodeficiency Virus (HIV) patients in University of Malaysia Medical Centre, Kuala Lumpur, Malaysia found a prevalence of $32 \%$ using PHQ-9 while scores from HADS showed $19 \%$ of depression rate among the respondents [45]. He concluded that depression rate was lower compared to those from the studies in western countries.

The prevalence obtained from this study also agrees with local

\begin{tabular}{|c|c|c|c|c|c|c|}
\hline Economic Status & & & Low Depression & Mild Depression & High Depression & p-value 0.64 not significant \\
\hline Good & & & $20(11.8)$ & $15(11.5)$ & $35(11.7)$ & \\
\hline Average & & & $62(36.5)$ & $41(31.5)$ & $103(34.3)$ & \\
\hline Poor & & & $88(51.8)$ & $74(56.9)$ & $162(54.0)$ & \\
\hline Year of Schooling & & & & & & 0.03 significant \\
\hline Below average & & & $80(47.0)$ & $55(42.3)$ & $135(45.0)$ & \\
\hline Average & & & $45(26.5)$ & $52(40.0)$ & $97(32.3)$ & \\
\hline Above average & & & $45(26.5)$ & $23(17.7)$ & $68(22.7)$ & \\
\hline Social Cohesion & & $\begin{array}{l}\text { Low } \\
0-2\end{array}$ & $\begin{array}{l}\text { Fair } \\
3-5\end{array}$ & $\begin{array}{l}\text { High } \\
6-9\end{array}$ & Total & $\begin{array}{c}0.05 \\
\text { Significant }\end{array}$ \\
\hline Depressed Male & & $21(67.7)$ & $8(25.9)$ & $2(6.5)$ & $31(100)$ & \\
\hline Depressed Female & & $112(80.6)$ & $27(19.4)$ & $0(0.0)$ & $139(100)$ & \\
\hline Negative Life Events & 0 & 1 & 2 & $3-9$ & Total & 0.04 Significant \\
\hline Depressed Male & $0(0.0)$ & $17(54.8)$ & $5(16.1)$ & $9(29.1)$ & $31(100.0)$ & \\
\hline Depressed Female & $32(23.0)$ & $33(23.7)$ & $29(20.9)$ & $45(32.3)$ & $139(100.0)$ & \\
\hline
\end{tabular}

Table 2: Association between Economic Status, Year of Schooling, Social Cohesion, Negative Life Events and Depression. 
studies $[44,46]$. Though lower in Uganda where Eugene ${ }^{48}$ found the prevalence of $8.1 \%$, a figure comparable to that of $9.6 \%$ reported by Chikezie et al. [47] in Zambia, 11.4\% reported by Adewuya et al. [45] in Nigeria and $2.7 \%$ reported by Marwick and Kaaya in rural Tanzania. All the studies above derived from sub-Saharan Africa used International Diagnostic Criteria to make a diagnosis of depression. Bradley in semi urban center in Cameroon used 400 HIV respondents and found a prevalence of $7 \%$ [47].

Ndu and co-workers [28], while studying prevalence of depression and role of support groups in its management, in a tertiary health facility in south-eastern Nigeria, found that $21.3 \%$ of the HIV/AIDS patients had borderline depression. Chikezie and co-workers [47] in Benin City, Nigeria while studying depression among people living with HIV/AIDS (PLWHA), using the Schedule for the Clinical Assessment of Neuropsychiatry (SCAN) and the Beck Depression Inventory (BDI) reported 29.3\%. The prevalence at Ilorin is comparable to Lagos University Teaching Hospital (LUTH), Lagos, Nigeria where Igie and co- workers [48] found that $42 \%$ of the respondents were severely depressed by the Hamilton Depression Scale Rating. Also comparable to Shehu and colleagues [49] at Aminu Kano Teaching Hospital, Nigeria who found the prevalence of $39.9 \%$ using the Hospital Anxiety and Depression Scale (HAD).

These variations in prevalence of depression may be due to the diagnose criteria used by these studies, in making diagnosis of depression, for example, while some used Hospital Anxiety Scale (HADS), some others studies might have used Diagnostic and Statistical Manual of Mental Disorders-IV (DSM-IV). Secondly, variations may also be due to the various stages of HIV in these patients compared to other studies.

Epidemiological findings point to a female preponderance in prevalence, incidence and morbidity risk of depressive disorders [50]. Prevalence of depression had been found to vary considerably based on gender [21]. Consistently, women had nearly double or triple the prevalence of depression compared to men [20]. Women $(68.7 \%)$ reported significant higher prevalence of depression than men (32.3\%) in the study of Averina and Colleagues, [51] in Russia. The above findings, $[20,21,51,52]$ was in consonant to our study. On the contrary, a South-African study [53] found the prevalence rate of depressive symptomatology to be almost equal in both sexes. The result of our study negates the findings that, in Africa, there was higher rates of depression among men than women in psychiatric institution [54]. Marital status had been found to interact with gender in accounting for variance in the prevalence rate of depression. In Australia, [55] for example, those who were separated or divorced PLWHA had a higher rate of depression. Similarly, another South-African Stress and Health study (SASH), found that mood disorders were more frequent among separated, widowed and divorced individuals and among people with only an elementary school level of education [56]. This was similar to our findings. In this study, the severity of depressive symptoms was similar between married, 14(8.2\%) and unmarried, 14(8.2\%) patients. However, in another study [57], there was a significant statistical correlation between marital status and depression. Women are much likely to experience negative social determinants than men because they carry the double burden of raising children and household work. Gender inequity in the couple relationship, was related to depressive mood, hence there is need to pay more attention to gender relations in future research on social determinants of depressive mood.

Previous research had found that age was one of the demographic characteristics that accounted for much of the variance in the prevalence of depression [20]. In a study in Nigeria [58], there was no significant association between depression and age. Similarly in Bongongo study [41], no relationship was found between age and depressive features among patients receiving HAART. Harvard Medial School reported that, depression could occur at any age, and that individual, may experience depression at different times of their lives for different reasons [59]. There were no significant differences $($ Pvalue $=0.79$ ) between age group and depression. This is similar to the finding of Bongongo and colleagues [41] in South-Africa, where age group was not significant $(\mathrm{p}$-value $=0.11)$.

The lowest depression prevalence rate was found among respondents with tertiary education, 17 (10.0\%). This contrasts with the findings in Canada, [55] where respondents, whose educational level were less than secondary education, had the lowest rate of depression and the highest prevalence rate of depression (13.4\%), was seen among those with tertiary education [55]. Education is a critical social determinants of health because, people with higher levels of education are healthier than people with lower levels of educational attainment. About 25 (8.3\%) were unemployed. Unemployment leads to poor physical mental health in a number of ways. When patients become unemployed, it is a stressful event that affects their self-esteems. Since employment generates income, a positive identity and the ability to live healthy lifestyles, unemployment leads to impoverishment, psychological stress and participate in health-threatening coping behaviours such as tobacco consumption, alcohol abuse, promiscuity. This is similar to another study [59], where depressive features were more common among the unemployed. Depression resulting from unemployment has increased over the years [60]. Six (2.0\%) were students. The implication of this age group is that, youth, the future of Nigeria, should be targeted for HIV interventions. Unemployment is also responsible for mental health problems such as depression. The highest prevalence rate of depression 129 (75.9\%) was seen in patients with an income level of less than twenty thousand Naira (N20,000), which is the minimum recommended income by the Federal Government of Nigeria.

This is similar to the findings in the province of Ontario, in Canadian Health Survey, where the highest prevalence of depression (18.4\%), was seen in household, with an income level of less than $\$ 10,000$ per year [20]. Income is the most significant social determinants of health, because it determines one's overall living conditions, affect one's psychological condition, and help shape one's diet and eating habits. Low-income people living in poverty, cannot afford healthy food, sufficient clothing and good housing all of which are necessary preconditions of good health.

Social cohesion occurs when specifies marginalized groups are not able to participate in their identity and social location. Social cohesion is based on four differences viz: denial of participation in civil affairs, denial of social funds, exclusion for social production and economic exclusion. In this study, Social Cohesion was very low in both males and females, $21(67.7 \%)$ and $112(80.6 \%)$ respectively among the depressed HIV patients. Only $2(6.5 \%)$ males had high social cohesion. This is statistically significant $(\mathrm{p}$-value $=0.005)$. Deprivation causes social exclusion when people are unable to participate in cultural, educational and recreational activities due to their poor social-economic conditions. In the long term social exclusion, negatively impacts on one's physical and mental health. Income inequality is a key public health issue that must be addressed by governments and policy makers by increasing minimum wage and social assistance levels.

Social support and good social relationship makes an important contribution to health and prevent the depression. Social support also 
helps to give people the emotional and practical resources they need. Belonging to a social network of communication and mutual obligatory makes people feel cared for, loved, esteemed and valued. This has a powerful protective effect on health. Therefore, good social relationship can reduce depression. On the other hand, low social support causes more stress and can accelerate or worsen the progression from HIV to AIDS [60]. Treatment included anti-depressants, as well as specific psychotherapy approaches (cognitive behaviour therapy and psychosocial counseling).

\section{Limitation of the Study}

There are few limitations of the study that may reduce the generalization of our findings. The relatively small sample may be a potential limitation. Self-reported measures to assess economic status and depressive symptoms were used. These were prone to participant response bias, such as low reported symptoms due to stigma. Moreover, like all cross-sectional studies, it is difficult to establish causal association between independent and dependent variables. Furthermore, a cultural measure was lacked in this study. In the era of economic globalization, it is important to research the cross-cultural generalization of existing explanatory models of Social Determinants of Health in depression and draw respective conclusions for policy recommendation and action.

\section{References}

1. WHO (2011) Depression. Mental Health World Health Organization.

2. School of Public Health (2005) Depression: The Public Health Dimension. University of Michigan, Fining Magazine.

3. Ohaeri JU, Jegede RO (1991) Depression and the general medical practitioner in Nigeria. Medicare 6: 7-11.

4. Cassano P, Fava M (2002) Depression and public health: an overview. J Psychosom Res 53: 849-857.

5. Arnsten JH, Demas PA, Grant RW, Gourevitch MN, Farzadegan $\mathrm{H}$, et al. (2002) Impact of active drug use on antiretroviral therapy adherence and viral suppression in HIV-infected drug users. J Gen Intern Med 17: 377-381.

6. Boarts JM, Sledjeski EM, Bogart LM, Delahanty DL (2006) The differential impact of PTSD and depression on HIV disease markers and adherence to HAART in people living with HIV. AIDS Behav 10: 253-261.

7. Bouhnik AD, Préau M, Vincent E, Carrieri MP, Gallais H, et al. (2005) Depression and clinical progression in HIV-infected drug users treated with highly active antiretroviral therapy. Antivir Ther 10: 53-61.

8. Kennedy CA, Skurnick J, Wan JY, Quattrone G, Sheffet A, et al. (1993) Psychological distress, drug and alcohol use as correlates of condom use in HIV-serodiscordant heterosexual couples. AIDS 7: 1493-1499.

9. Kalichman SC, Kelly JA, Rompa D (1997) Continued high-risk sex among HIV seropositive gay and bisexual men seeking HIV prevention services. Health Psychol 16: 369-373.

10. Safren SA, Otto MW, Worth JL, Salomon E, Johnson W, et al. (2001) Two strategies to increase adherence to HIV antiretroviral medication: life-steps and medication monitoring. Behav Res Ther 39: 1151-1162.

11. U.S. Preventive Task Force (2010) Screening for Depression in Adults: Recommendation Statement. Am Fam Physician 82: 976-979.

12. Ciesla JA, Roberts JE (2001) Meta-analysis of the relationship between HIV infection and risk for depressive disorders. Am J Psychiatry 158: 725-730.

13. Sadock BJ, Kaplan HI, Sadock VA (2007) Synopsis of Psychiatry: Behavioral Sciences/clinical Psychiatry. (9th Edn.), Philadephia Lippincott Williams and Willkins.

14. Morrison MF, Petitto JM, Ten Have T, Gettes DR, Chiappini MS, et al. (2002) Depressive and anxiety disorders in women with HIV infection. Am J Psychiatry 159: 789-796.

15. National Institute of Mental Health (NIMH) (2004) Depression and HIVIAIDS.

16. Lai DWL, Tong HM (2009) Comparism of social status determinants of depressive symptoms among elderly Chinese in Guangzhou, Hong King and Taipei. J Gerontol Geriatr 4: 58-65.

17. Robins LN, Reiger DA (1991) Psychiatric disorders in America: The Epidemiologic Catchment Area Study New York. The free Press.

18. Kessler RC, McGonagle KA, Zhao S, Nelson CB, Hughes M, et al. (1994) Lifetime and 12-month prevalence of DSM-III-R psychiatric disorders in the United States. Results from the National Comorbidity Survey. Arch Gen Psychiatry 51: 8-19.

19. Patten SB (2000) Incidence of major depression in Canada. CMAJ 163: 714 715.

20. Offord DR, Boyle MH, Campbell D, Goering P, Lin E, et al. (1996) One-year prevalence of psychiatric disorder in Ontarians 15 to 64 years of age. Can J Psychiatry 41: 559-563.

21. Wade TJ, Cairney J, Pevalin DJ (2002) Emergence of gender differences in depression during adolescence: national panel results from three countries. $J$ Am Acad Child Adolesc Psychiatry 41: 190-198.

22. Lorant $V$, Deliège $D$, Eaton $W$, Robert $A$, Philippot $P$, et al. (2003) Socioeconomic inequalities in depression: a meta-analysis. Am J Epidemiol 157: 98-112.

23. Goode E (1997) Deviant Behavior. Upper Saddle River, Prentice Hall.

24. Canada (1996) Houses of Commons Standing Committee on health $5 / 32$ Ottawa.

25. Canada (2000) Legacy discussion paper. Health Canada. Ottwa.

26. Li L, Lee SJ, Thammawijaya P, Jiraphongsa C, Rotheram-Borus MJ (2009) Stigma, social support, and depression among people living with HIV in Thailand. AIDS Care 21: 1007-1013.

27. Araoye MO (2003) Data collection in: Research methodology with statistics for Health and social sciences. Nathadex publishers, Ilorin,130-159.

28. Ndu AC, Arinze SU, Aguwa EN, Obio IE (2011) Prevalence of depression and role of support group in its management: A study of Adult HIVIAIDS patients attending HIVIAIDS Clinic in a tertiary health facility in South-eastern Nigeria. Journal of Public Health and Epidemiology 3: 182-86.

29. World Health Organization (2008) A Closing the gap in a generation: health equity through action of on the social determinants of health.

30. World Health Organization (2010) A Comceptual Framework for Action on the Social Determinants of Health.

31. Stewart DE (2007) Social determinants of women's mental health. J Psychosom Res 63: 223-224.

32. Phillips MR, Yang G, Zhang Y, Wang L, Ji H, et al. (2002) Risk factors for suicide in China: a national case-control psychological autopsy study. Lancet 360: 1728-1736.

33. Pence BW, Reif S, Whetten K, Leserman J, Stangl D, et al. (2007) Minorities, the poor, and survivors of abuse: HIV-infected patients in the US deep South. South Med J 100: 1114-1122.

34. Ewing JA (1984) Detecting alcoholism. The CAGE questionnaire. JAMA 252 1905-1907.

35. Asch SM, Kilbourne AM, Gifford AL, Burnam MA, Turner B, et al. (2003) Underdiagnosis of depression in HIV: who are we missing? J Gen Intern Med 18: $450-460$.

36. Bing EG, Burnam MA, Longshore D, Fleishman JA, Sherbourne CD, et al (2001) Psychiatric disorders and drug use among human immunodeficiency virus-infected adults in the United States. Arch Gen Psychiatry 58: 721-728.

37. O'Sullivan C (2004) The psychosocial determinants of depression: a lifespan perspective. J Nerv Ment Dis 192: 585-594.

38. Judd F, Komiti A, Chua P, Mijch A, Hoy J, et al. (2005) Nature of depression in patients with HIVIAIDS. Aust N Z J Psychiatry 39: 826-832.

39. Akena DH, Musisi S, Kinyanda E (2010) A comparison of the clinical features of depression in HIV-positive and HIV-negative patients in Uganda. Afr J Psychiatry (Johannesbg) 13: 43-51.

40. Israeethika J, Narin H, Nuttoru P, Vitrol L, Buranee K, et al. (2011) The effect of cognitive behavioural therapy and changes of depressive symptoms among Thai Adult HIV-Infected Patients. World Journal of AIDS 1: 15-22. 
Citation: Shittu RO, Issa BA, Olanrewaju GT, Mahmoud AO, Odeigah LO, et al. (2013) Prevalence and Correlates of Depressive Disorders among People Living with HIV/AIDS, in North Central Nigeria. J AIDS Clin Res 4: 251. doi: 10.4172/2155-6113.1000251

41. Bongogo T, Tumbo J, Govender I (2013) Depressive features among adult patients receiving HAART. S Af J Psych 19: 31-34.

42. Mello VA, Segurado AA, Malbergier A (2010) Depression in women living with HIV: clinical and psychosocial correlates. Arch Womens Ment Health 13: 193199.

43. Tung MY, May Lee HG, Chong Guan NG, John TJ Teong, Adeeba K (2009) Identifying depression among the Human Immunodeficiency Virus (HIV) patients in University Malaya Medical Centre, Kuala Lumpur, Malaysia. ASEAN Journal of Psychiatry 10: 1-13.

44. Kinyanda E, Hoskins S, Nakku J, Nawaz S, Patel V (2011) Prevalence and risk factors of major depressive disorder in HIVIAIDS as seen in semi-urban Entebbe district, Uganda. BMC Psychiatry 11: 205.

45. Adewuya AO, Afolabi MO, Ola BA, Ogundele OA, Ajibare AO, et al. (2008) Relationship between depression and quality of life in persons with HIV infection in Nigeria. Int J Psychiatry Med 38: 43-51.

46. Gaynes BN, Pence BW, Atashili J, O'Donnell J, Kats D, et al. (2012) Prevalence and predictors of major depression in HIV-infected patients on antiretroviral therapy in Bamenda, a semi-urban center in Cameroon. PLoS One 7: e41699.

47. Chikezie UE, Otakpor AN, Kuteyi OB, James BO (2013) Depression among people living with human immunodeficiency virus infection/acquired immunodeficiency syndrome in Benin City, Nigeria: a comparative study. Niger J Clin Pract 16: 238-242.

48. Igie IK, Udoh M (2011) Prevalence of depression in HIVIAIDS patients, Lagos State University Hospital (LUTH), Lagos, Nigeria. International AIDS society; 6th IAS conference on HIV Pathogenesis, treatment and prevention: Rome, Italy.

49. Shehu S, Muktar G (2008) Prevalence and factors associated with depression in HIVIAIDS patients aged 15-25 years at Aminu Kano Teaching Hospital, Nigeria. Journal of Child and Adolescent Mental Health 20: 95-99.
50. Piccinelli M, Wilkinson G (2000) Gender differences in depression. Critical review. Br J Psychiatry 177: 486-492.

51. Averina M, Nilssen O, Brenn T, Brox J, Arkhipovsky VL, et al. (2005) Social and lifestyle determinants of depression, anxiety, sleeping disorders and selfevaluated quality of life in Russia--a population-based study in Arkhangelsk. Soc Psychiatry Psychiatr Epidemiol 40: 511-518.

52. Ihezue UH, Kumaraswamy N (1986) Socio-demographic factors of depressive illness among Nigerians. Acta Psychiatr Scand 73: 128-132.

53. Mossa MYH, Jennah FY (2007) Treating depression in HIVIAIDS. SouthAfrican Journal of Psychiatry 13: 86-89.

54. Culbertson FM (1997) Depression and gender. An international review. Am Psychol 52: 25-31.

55. Australia Bureau of Statistics 2006

56. Herman AA, Stein DJ, Seedat S, Heeringa SG, Moomal H, et al. (2009) The South African Stress and Health (SASH) study: 12-month and lifetime prevalence of common mental disorders. S Afr Med J 99: 339-344.

57. Klerman GL, Weissman MM (1989) Increasing rates of depression. JAMA 261 2229-2235.

58. Agbir TM, Audu MD, Adebowale TO, Goar SG (2010) Depression among medical outpatients with diabetes: a cross-sectional study at Jos University Teaching Hospital, Jos, Nigeria. Ann Afr Med 9: 5-10.

59. President and Fellows of Harvard College (2007) Depression, sex and age. Harvard Health Publications, Cambridge, MA, 1-5.

60. Leserman J, Pence BW, Whetten K, Mugavero MJ, Thielman NM, et al. (2007) Relation of lifetime trauma and depressive symptoms to mortality in HIV. Am J Psychiatry 164: 1707-1713. 